DOI: https://doi.org/10.33989/2075-146x.2021.27.247051

УДК 37.014(09)“1862/1919”

ІРИНА ДІДЕНКО

ORCID: 0000-0003-2047-7239

\title{
ОЛЕНА ФІЛАТОВА
}

ORCID: 0000-0001-7585-3938

Київський національний університет імені Тараса Шевченка

\section{ЕСТЕТИЧНЕ ВИХОВАННЯ УЧНІВСЬКОЇ МОЛОДІ В КОНТЕКСТІ ПЕДАГОГІЧНИХ З’їЗДІВ 1862 - 1919 РОКІВ}

\begin{abstract}
Представлене дослідження є історико-педагогічним та висвітлює питання естетичного виховання учнівської молоді в контексті такого потужного явища освіти другої половини XIX - початку XX століть, як педагогічні з'їзди. 3'ясовано: питання естетичного виховання порушувалось майже під час кожного з’їзду у період 1862-1919 рр.; делегати з’їздів виокремлювали естетичне виховання як необхідний елемент всебічного та гармонійного розвитку школярів; до основних засобів естетичного виховання відносили вивчення творів вітчизняних і світових письменників та митців, екскурсії, національними традиціями, творча праця.
\end{abstract}

Ключові слова: естетичне виховання, учнівська молодь, педагогічний з '̈зд, всебічний $i$ гармонійний розвиток особистості, засоби естетичного виховання дітей

Актуальність теми статті. На початку XXI століття, в епоху швидких змін і технологічних проривів, актуальним залишається питання виховання гармонійної особистості. Україна на державному рівні у Законі України «Про освіту» метою повної середньої освіти визначає різнобічний розвиток і виховання особистості. Одним із елементів всебічного розвитку дитини поряд 3 фізичним, трудовим, моральним, національним вихованням, безсумнівно, є естетичне виховання.

У курсі сучасної середньої загальноосвітньої школи естетичне виховання здійснюється в інтегрованому курсі «Мистецтво», який охоплює образотворче та музичне мистецтво, а також у курсах вітчизняної і зарубіжної літератури, історії, тощо. Необхідною умовою для успішної реалізації вимог освітнього законодавства до повноцінного і всебічного розвитку особистості є підготовка кваліфікованих педагогічних кадрів. Саме до змісту курсу «Педагогіка» та «сторія педагогіки» педагогічних закладів вищої освіти можна включити матеріали даного дослідження, які розкривають сутність підходів до всебічного розвитку особистості взагалі та до естетичного виховання зокрема 3 точки зору педагогів-учасників такого потужного та прогресивного явища освіти кінця XIX - початку XX століть, як педагогічні з'ізди. Ця тема є малодослідженою, хоча саме вивчення історичного досвіду є запорукою успіху сучасних підходів до естетичного виховання.

Дослідження теми у науковій літературі. Освітянські з’їзди неодноразово ставали предметом наукового пошуку вітчизняних і закордонних дослідників. Деякі з них досліджували зокрема питання окремих видів виховання в роботі з'їздів. Так, С. Золотухіна в контексті педагогічних з'їздів розглядала виховуюче навчання в дисципліні «Закон Божий» (Золотухіна, 1995). 3. Нагачевська досліджувала питання дошкільного виховання в роботі педагогічних з'їдів (Нагачевська, 1995, с. 58). Г. Котломанітова вивчала освітянські з'їзди 3 позиції релігійного виховання (Котломанітова, 2007, с. 105-106). Окремих аспектів естетичного виховання у роботі чотирьох освітянських з'їздів (з 1911 по 1914 рр.) торкнулась О. Донченко, а саме: ролі мистецтва в родині і дитячому садочку, форм естетичного виховання (виставки, музеі, екскурсії, театр, кіно, літературні твори) (Донченко, 2005). Проте, глибокого аналізу динаміка розгляду проблем естетичного виховання під час освітянських з'їздів, починаючи з виникнення такого явища, як «педагогічний з'їзд» у 60-х роках ХІХ століття та закінчуючи періодом радикальних змін у системі освіти під час суспільно-політичної перебудови у кінці 10х років XX століття на території сучасної України, не зазнавала. Що й зумовило актуальність даного дослідження.

Отже, метою даного дослідження стало вивчення здобутків педагогічних з'їздів 1862 - 1919 років щодо визначення сутності естетичного виховання, його потенціалу у вихованні гармонійної особистості учнів, засобів здійснення естетичного виховання.

До початку XX століття окремого питання про естетичне виховання під час педагогічних з'їдів не порушувалось. Так, учасниками Лебединського з’їду (20 - 25 липня 1862 року) наголошувалось на необхідності всебічного розвитку учнів, але основною метою виховного процесу делегати вважали моральне виховання учнівської молоді. 
Під час Другого з’їзду російських діячів з технічної та професійної освіти (м. Москва, 1895 - 1896 рр.) естетичне виховання також не було виокремлено, а розглядалось, як частина сімейного, трудового, морального та фізичного виховання. Делегати запропонували створення літніх дитячих колоній, де учні могли б відновлювати свої фізичні та духовні сили. До всебічного розвитку учнів пропонувалось долучати родину, а спілкування дитини з учителем пропонувалось продовжувати у позашкільний час, щоб «...практичним шляхом учитель знайомив дітей з великими надбаннями людського розуму, пробуджуючи в дітях самоповагу, повагу до праці та повагу до людей...» (Резолющии съезда русских деятелей..., 1898, с. 138-139). Делегати наполягали на важливості екскурсій, ігор на свіжому повітрі та дитячих клубів для гармонійного розвитку учнів (Резолюиии съезда русских деятелей..., 1898).

Учасники Першого Загальноземського з’їзду з народної освіти у 1911 році всебічний розвиток дитини пов'язували з розвитком фізичного та трудового виховання. Делегати зауважували, що ручна праця покликана «...переслідувати педагогічні цілі всебічного розвитку учнів» (Первый общеземский съезд..., 1912, с. 148). Особливим досягненням цього з’їду було рішення про необхідність залучення до викладання ручної праці не ремісника, а саме педагога, якому мала надаватись свобода у виборі методів, прийомів, засобів і змісту викладання з урахуванням вікових особливостей учнів (Первый общеземский съезд..., 1912).

Вперше проблема естетичного виховання учнів окремо обговорювалась на з’їді інспекторів народних і вищих початкових училищ (м. Чернігів, 14 - 18 квітня 1916 року). Учасники з’їзду зауважили, що гармонійного розвитку особистості учнів можна досягти лише через співпрацю школи та родини через літературно-музичні вечори, екскурсії тощо. Завдання самої школи делегатами не зводились лише до надання школярам знань, але й до розвитку загальнолюдських цінностей. Школа, з точки зору педагогів-учасників. «має виховати освічену людину, всебічно та гармонійно розвинуту, доброго громадянина, вірного сина своєї церкви та батьківщини...» (Делекторский (Ред.), 1916, с. 130).

Під час цього з”ізду було введено поняття «розумного дозвілля», яке педагогами вважалось надзвичайно корисним інструментом гармонійного духовного розвитку особистості учнів, що сприяє «... розвитку естетичних почуттів дітей, товариськості та м'якості їхнього характеру, будить чуйність і розуміння всього прекрасного...» (Делекторский (Ред.), 1916, с. 23). Саме таке дозвілля було покликано об'єднати родину та школу для досягнення важливої мети - всебічного розвитку дитини.

«Розумним дозвіллям» учасники з'їзду називали: організацію вистав за участю дітей і батьків; літературних і музичних вечорів, до організації яких долучались учителі, які декламували вірші, співали, грали на музичних інструментах; запрошувались представники церковного хору, музиканти струнних і духових оркестрів (Делекторский (Ред.), 1916, с. 23-24).

На педагогічному з'їзді в Києві (12 - 19 квітня 1916 року) також порушувалось питання щодо важливості взаємодії сім’ї та школи для всебічного розвитку дитини. Саме виховання визнавалось найпершим і найважливішим завданням школи, воно, з точки зору учасників з’їзду, мало здійснюватися «на засадах моральності та християнської любові» та призводити до «гармонійного розвитку духовних та фізичних сил учня» (Труды Киевского педагогического съезда..., 1916, с. 584).

Учасники з'їзду, особливо наголошуючи на важливості створення бібліотек для всебічного розвитку дитини, проголосували за відновлення закону, що давав право педагогічним радам «поповнювати учнівські бібліотеки книжками за своїм вибором, а не тільки з числа тих, що рекомендовані Вченим комітетом Міністерства народної освіти...» (Труды Киевского педагогического съезда..., 1916, с. 599). На цьому ж засіданні делегати постановили, що необхідно при Музеї Цесаревича Олексія створити постійно діючу комісію спеціалістів, яка б створювала бібліотеки та давала фахові поради педагогічним радам щодо книжок, якими варто було б поповнювати бібліотечні фонди.

Серйозно підійшли учасники з’їду до питання організації екскурсій та їх користі для гармонійного розвитку учнів. Якщо до цього екскурсії мали переважно випадковий характер, то делегати запропонували «ретельно планувати екскурсії, організовувати їх для кожного класу протягом кожного навчального року. Починати було рекомендовано з ознайомлення дітей із місцевістю навколо їхнього навчального закладу (там само).

Окремо делегати цього з'їзду обговорювали питання естетичного виховання. Розвиток естетичних почуттів і художнього смаку учнів. На їхню думку, мав розпочинатись із досить простих щоденних речей: охайний зовнішній вигляд школярів, гарну обстановку в школі (Труды Киевского педагогического съезда ..., 1916, с. 597). У подальшому учнів мали залучати до створення навчально-допоміжних посібників, організації виставок $\mathrm{i}$ вистав, до участі в художніх вечорах. Також для дітей пропонувалось організовувати факультативні курси зі співу та художнього читання. Учасники з'їду обговорювали можливість створення «спеціальних естетичних комісій» при педагогічних радах для системного підходу до організації «естетичних заходів» (Труды Киевского педагогического съезда..., 1916, с. 598).

Після Лютневої революції 1917 року акценти в підходах до естетичного виховання змінились. По-перше, це було пов'язано із зменшенням зовнішнього надзору і, як наслідок, з більшою свободою, яку отримали школи, у змісті та методах навчання та виховання. По-друге, потужності набрала ідея національного самовизначення, а з нею й ідея національного виховання. 
Так, під час Другого Всеукраїнського вчительського з’їзду (10-12 серпня 1917 року, м. Київ) делегати прийняли основу «проекту єдиної української школи», який передбачав визначення виховання основним завданням нової української школи (Зайченко, 2013, с. 358). Згідно з новим проектом «навчальний процес мав будуватися навколо дитини, а навчання мало стати засобом виховання» (Зайченко, 2013, с. 384).

Учасники з'їзду наголошували на тому, що національне виховання має здійснюватися шляхом ознайомлення дітей із рідною мовою, життям і культурою свого народу. У підходах до естетичного виховання проголошувалась певна свобода: у школі від тоді не мали примушувати учнів «досконало вивчати різні види мистецтва», завданням школи стало виховання волі та розвиток творчих здібностей дитини (Зайченко, 2013, с. $385)$.

Жовтнева революція 1917 року, у свою чергу, внесла певні корективи у підходи до естетичного виховання. Національне виховання новою владою трактувалось, як виховання «майбутнього громадянина соціалістичної республіки» (Резолюции 1-го Всероссийского Съезда..., 1918, с. 3).

Таким чином, під час Першого Всеросійського з’їзду з просвіти (м. Москва, 25 серпня - 4 вересня 1918 року) трудовий принцип проголошувався основним у шкільному навчально-виховному процесі. Всебічний розвиток дитини мав відбуватися через розумову та фізичну працю. Теж саме стосувалось і естетичного виховання, яке мало здійснюватися «творчу працю дитини, різні форми дитячого дозвілля та відпочинку» (там само).

Проте, незважаючи на загальну тенденцію підпорядкування школи соціалістичній владі, українські педагоги продовжують боротися за національну ідею. Наприклад, Делегати з’їзду діячів середньої української школи зібрався (січень 1919 року) наголошували на тому, що «школа має бути національною та демократичною», а естетичне виховання потрібно здійснювати через збереження національних традицій (Калинський, 1918-1919, c. 147).

Висновки. Отже, на основі аналізу історичних першоджерел можемо стверджувати, що естетичне виховання жваво обговорювалось під час з'їздів кінця XIX - початку XX століть та вважалось одним із важливих елементів всебічного та гармонійного розвитку дитини.

У різні часи в залежності від політичної ситуації, естетичне виховання розглядалось або як окремий вид виховання (з 1916 року) або у тісному зв’язку з трудовим, моральним, національним і навіть фізичним вихованням (у другій половині XIX - першому 10-річчі XX століть). Основними засобами естетичного виховання, які обговорювались делегатами педагогічних з’їзів були: вивчення творів вітчизняних і світових письменників і митців, екскурсії, ознайомлення з рідним краєм, національними традиціями, творча праця, різні форми дитячого відпочинку та дозвілля, творчі та музичні вечори, прищеплення смаку через охайну зовнішність. На допомогу педагогічним радам створювались естетичні комісії та ради спеціалістів, які надавали поради щодо відбору літератури для шкільних бібліотек.

Таким чином, педагоги під час освітянських з’їздів другої половини XIX - початку XX століть розробили основні підходи до естетичного виховання, як невід’ємного компоненту гармонійного розвитку особистості учнів.

Перспективою подальших наукових досліджень можна окреслити вивчення питання, яким чином резолюції педагогічних з’їздів щодо естетичного виховання впливали на реальний навчально-виховний процес у школах, які пропозиції були реалізовані, а які так і залишились на папері.

\section{Список використаних джерел}

Делекторский, Ф. И. (Ред.). (1916). Отчет о бывшем в Чернигове 14-18 апреля 1916 г. съезде инспекторов народных и высших начальных училищ, Черниговской губернии. Чернигов: Типография Губернского Земства.

Донченко, О. В. (2005). Проблема естетичного виховання дітей дошкільного віку в педагогічній думці Украйни (кінеиь XIX-початок XX cm.). (Дис. канд. пед. наук). Харків.

Зайченко, І. В. (2013). Освіта $і$ педагогічна думка в Украӥні у XIX - на початку XX ст. Київ: ТОВ ЦП «КОМПРИНТ».

Золотухіна, С. Т. (1995). Розвиток теорї та практики виховуючого навчання в історї вітчизняної педагогічної думки (IX-XIX cm.). (Дис. д-ра пед. наук). Харків.

Калинський, В. (1918-1919). 3’їзд діячів середньої української школи. Вільна українська школа. 8-9, $145-149$.

Котломанітова, Г. О. (2007). Релігійне виховання в історї шкільної освіти Украӥни (60-ті роки XIX ст. - 30-ті роки XX ст.). (Дис. канд. пед. наук). Полтава.

Нагачевська, 3. I. (1995). Становлення і розвиток украӥнського суспільного дошкільного виховання в Східній Галичині (1869 - 1939 роки). (Дис. канд. пед. наук). Київ.

Первый общеземский съезд по народному образованию 1911 года: доклады. (1912). (Т. 2). Москва: Типография Вильде.

Резолющии 1-го Всероссийского Съезда по Просвещению, созванного Народным Комиссариатом по Просвещению в Москве 25 августа 1918 г. (1918). Москва: Издание Отдела Съездов Народного Комиссариата по Просвещению. 
Резолюичи съезда русских деятелей по техническому и профессиональному образованию бывшего в Москве в 1895-1896 2. (1898). Санкт-Петербург: Типография И.Н. Скороходова.

Труды Киевского педагогического съезда 12-19 апреля 1916 года. (1916). Киев: Типография Т-ва И.Н.Кушнерев и Ко.

\section{References}

Delektorskyi, F. I. (Ed.). (1916). Otchet o byvshem v Chernigove 14-18 aprelya 1916 g. siezde inspektorov narodnykh I vysshykh nachalnykh uchylishch Cherigovskoy gubernii [Report on the Congress of inspectors of people's and higher primary schools of Chernigiv gubernia]. Chernigiv: Tipografia Gubernskogo Zemstva [in Russian].

Donchenko, O. V. (2005). Problema estetychnogo vykhovannia ditey doshkilnogo viku v pedagogichniy dumtsi Ukrainy (kinets XIX - pochatok XX st. [Problems of aesthetic education in pedagogical studies of Ukraine (late XIXearly XX centuries)]. (PhD diss.). Kharkov [in Russian].

Kalynsky, V. (1918-1919). Ziizd diyachiv serednyoi ukrainskoi shkoly [Congress of the teachers of the Ukrainian secondary school]. Vilna ukrainska shkola [Ukrainian Higher School], 8-9, 145-149 [in Ukrainian].

Kotlomanitova, G. O. (2007). Relygiyne vykhovannia v istoriyi shkilnoyi osvity Ukrainy (60-ti roky XIX st. - 30-ti roky $X X$ st.) [Religious education in the history of school education of Ukraine (60s of XIX-30s of XX)]. (PhD diss.). Poltava [in Ukrainian].

Nagachevska, Z. I. (1995). Stanovlennia I rozvytok ukrainskogo suspilnogo doshkilnogo vykhovannia v Skhidniy Halychyni (1869-1939 roky) [Emergence and development of Ukrainian social pre-school education in the Eastern Halyshyna (1869-1939)]. (PhD diss.). Kyiv [in Ukrainian].

Pervie obshchezemsky siezd po narodnomu obrazovaniiu 1911 goda: doklady [The First All-Zemstvo Congress on People's Education: reports]. (1912). (Vol. 2). Moskva: Tipografia Vilde [in Russian].

Rezolutsii 1-go Vstrossiyskogo Siezda po Prosveshcheniu, sozvannogo Narodnym Komossariatom po Prosveshcheniu $v$ Moskve 25 avgusta 1918 g. [Resolutions of the First All-Russian Congress on Education, called by People's Commissariat of Education in Moscow on the 25th of August 1918]. (1918). Moskva: Izdanie Otdela Siezdov Narodnogo Komissariata po Prosveshcheniu [in Russian].

Rezolutsii siezda russkikh deiateley po tekhnicheskomu I professionalnomu obrazovaniiu byvshego v Moskve v 1895$1896 \mathrm{~g}$. [Resolutions of the Congress of the Specialists in Technical and Vocational Education, organized in Moscow in 1895-1896]. (1898). Sankt-Peterburg: Tipografia I.N. Skorokhodova [in Russian].

Trudy Kievskogo pedagogicheskogo siezda 12-19 aprelia 1916 goda [Materials of the Kyiv Pedagogical Congress in 12-19 of April 1916]. (1916). Kiev: Tipografia T-va I.N. Kushnerev i Ko [in Russian].

Zaychenko, I. V. (2013). Osvita i pedagogichna dumka d Ukraini u 19 - na pochatku 20 st. [Education and Pedagogy in Ukraine of the 19th - early 20th century]. Kyiv: TOV TSP "KOMPRINT" [in Ukrainian].

Zolotukhina, S. T. (1995). Rozvytok teoriyi ta praktyky vykhovuyuchogo navchannia $v$ istoriyi vitchiznianoyi pedagogichnoi dumky (IX-XIX st.) [The development of theory and practice of upbringing education in the history of domestic pedagogical studies (IX-XIX centuries)]. (D diss.). Kharkiv [in Ukrainian].

\section{DIDENKO I., FILATOVA O.}

Taras Shevchenko National University of Kyiv, Ukraine

\section{AESTHETIC EDUCATION IN THE CONTEXT OF PEDAGOGICAL CONGRESSES OF 1862 - 1919}

Current research is a historic and pedagogical study. It uncovers the problem of aesthetic education in the context of such a meaningful phenomenon of the education of the late 19th century and the early 20th century as pedagogical congresses. The study has proved that the issues of the aesthetic education were considered during almost every pedagogical congress from 1862 till 1919. This type of education was recognized as the necessary part of comprehensive and harmonious development of the child's personality. Under different political conditions aesthetic education was discussed during the pedagogical congresses either as a separate issue or as an element of other types of education: labor, ethical, national and even physical ones. The main methods and means of the aesthetic education considered by the participants of the pedagogical congresses were the following ones: familiarizing with the works of the prominent foreign and national authors, excursions, getting to know the native land, national traditions, creative labor, different forms of recreation and entertainment, art and musical events, taking care of your appearance. For supporting pedagogical councils, the delegates of the congresses suggested to create aesthetic committees and professional councils. To cut the long story short, the participants of the pedagogical congresses were very attentive to the issues of the aesthetic education and considered it as one of the necessary elements of harmonious development of 
the personality What remained uncovered was the degree of implementation of the solutions and recommendations of the participants of the pedagogical congresses in the educational process of the schools, namely, what ideas were introduced and what left just on the paper.

Key words: comprehensive development, harmonious development of the personality, aesthetic education, pedagogical congress

Стаття надійшла до редакції 03.02.2021 р.

DOI: https://doi.org/10.33989/2075-146x.2021.27.247053

УДК 376.3.06:502

СЕРГІЙ ДУДКО

ORCID: 0000-0002-2560-0825

Полтавський обласний інститут післядипломної педагогічної освіти

ім. М. В. Остроградського

\section{ФОРМУВАННЯ ЗДОРОВЯ'ЗБЕРЕЖУВАЛЬНОЇ КОМПЕТЕНТНОСТІ ЯК НАПРЯМ РЕАЛІЗАЦЇ̈ ЦІЕЙ СТАЛОГО РОЗВИТКУ}

У статті розкрито актуальність проблематики формування здоров'язбережувальної компетентності як необхідної умови для здорового та безпечного життя, що має сприяти досягненню глобальних цілей сталого розвитку суспільства. Проаналізовано нормативноправові документи в галузі освіти, які спрямовують освітній процес на необхідність цілісного підходу до формування здоров'язбережувальної компетентності, засвідчують потребу в новому розумінні педагогами ролі здоров’я, що дасть можливість кожному громадянину жити повноцінним сталим життям. Зазначається, що сформована здоров'язбережувальна компетентність випускника освітнього закладу збагачує комплексний розвиток його особистості на засадах сталого розвитку суспільства.

Ключові слова: здоров'язбережувальні компетентності, ключові компетентності, освітній процес, освіта сталого розвитку, державні стандарти, иілісний підхід, освітня галузь

Актуальність проблеми. Нагальною потребою розбудови сьогоднішнього українського суспільства стає формування системи цінностей, складової культурного світобачення кожного громадянина, яка не залежала б від економічного розвитку, зміни політичної влади, у якій би захист і збереження природи, турботу про людину, iï здоров'я й дотримання пї прав вважались такими ж важливими, як і саме життя. Актуальність теми представленого дослідження обумовлюється усвідомленням необхідності змін в освітній парадигмі України щодо формування сталого розвитку суспільства, що сьогодні вже є стратегічним завданням усієї світової спільноти (Аналіз державних стратегічних..,, 2017, с. 10). Постає проблема створення сталих освітніх середовищ та організації такої моделі навчання, в основі якої мають закладатися широкі міждисциплінарні знання, які базуватимуться на комплексному підході до розвитку особистості школярів, котрі в подальшому змогли б забезпечити здоров'язбереження, стабільність і ефективність існування сучасної цивілізації на засадах цілісності природного оточення, економічної життєздатності та соціальної справедливості для нинішніх $\mathrm{i}$ майбутніх поколінь. Отже, постає необхідність переорієнтації вітчизняної освіти на цілі сталого розвитку, в яких четвертою складовою визначено якісну освіту.

Аналіз попередніх досліджень. У запроваджених нових Державних стандартах початкової та базової середньої освіти і нових базових навчальних планів набуття ключових компетентностей відбувається 3 урахуванням засад сталого розвитку суспільства (Державний стандарт початкової освіти, 2019, с. 3). Національна стратегія розбудови безпечного й здорового освітнього середовища в новій українській школі (Про національну стратегію..., 2020, с. 5) також розроблена на підтримку Цілей сталого розвитку, проголошених ООН (резолюція Генеральної Асамблеї ООН від 25 вересня 2015 року № 70/1) і підтриманих Україною відповідно до Указу Президента України від 30 вересня 2019 року № 722 «Про Цілі сталого розвитку України на період до 2030 року» (Аналітична доповідь. 2017, с. 84.) Поняття сталого розвитку в його сучасному значенні було сформульовано в доповіді Міжнародної комісії з навколишнього середовища та розвитку (Комісія Брутланд) у 1987 році. Сталий розвиток розглядається як такий, що забезпечує збалансоване вирішення 